\title{
Struktur Komunitas Asteroidea dan Holothuroidea di Pantai Melayu dan Pantai Sembulang Pulau Rempang Kota Batam
}

\section{Community Structure of Asteroidea and Holothuroidea at Melayu and Sembulang Beach Rempang Island, Batam City}

\section{Hazlinda Frisca, Lani Puspita*, Fauziah Syamsi}

\author{
Program Studi Pendidikan Biologi Universitas Riau Kepulauan, *Corespondent email: \\ puspita.lani@gmail.com
}

Received: 20 October 2020 | Accepted: 04 Desember 2020 | Published: 30 Desember 2020

\begin{abstract}
Abstrak. Echinodermata adalah salah satu kelompok kewan yang dapat dijumpai di ekosistem pantai. Hingga saat ini penelitian mengenai struktur komunitas Echinodermata belum pernah dilakukan di Pulau Rempang Kota Batam. Penelitian ini bertujuan untuk mengetahui struktur komunitas Asteroidea dan Holothuroidea (dua kelas dari filum Echinodermata) di Pulau Rempang, khususnya di Pantai Sembulang (sisi Timur) dan Pantai Melayu (sisi Barat). Jenis penelitian ini adalah penelitian eksplorasi. Pada penelitian ini ditetapkan 2 stasiun pengamatan, yaitu Stasiun 1 di Pantai Sembulang dan Stasiun 2 di Pantai Melayu. Pengambilan contoh dilakukan dengan metode line transect. Setiap stasiun terdiri atas 3 transek. Berdasarkan hasil penelitian, ditemukan 7 spesies di Pantai Sembulang, yaitu: Archaster typicus, Craspidaster hesperus, Protoreaster nodosus, Holothuria atra, Holothuria scabra, Synapta maculata, dan Synapta sp., dengan nilai Indeks Keanekaragaman 1,92, Indeks Keseragaman 0,69, dan Indeks Dominansi 0,08. Sedangkan di Pantai Melayu, ditemukan 2 spesies, yaitu: A. typicus dan Cucumarid sp., dengan nilai Indeks Keanekaragaman 0,08, Indeks Keseragaman 0,41, dan Indeks Dominansi 0,98. Nilai Indeks Kesamaan Komunitas Asteroidea dan Holothuroidea di Pantai Sembulang dan Pantai Melayu adalah 0,02 (rendah).
\end{abstract}

Kata kunci: Struktur Komunitas, Asteroidea, Holothuroidea, Pulau Rempang.

Abstract. Echinoderms are a group of animals that can be found in coastal ecosystems. Until now, research on the structure of the Echinoderms community has never been carried out on Rempang Island, Batam City. This study aims to determine the community structure of Asteroidea and Holothuroidea (two classes of the Echinoderms phylum) in Rempang Island, particularly in Sembulang Beach (East side) and Pantai Melayu (West side). This is an exploratory research. In this study, 2 observation stations were established, namely Station 1 on Sembulang Beach and Station 2 on Pantai Melayu. Sampling was done by using the line transect method. Each station consists of 3 transects. Based on the results of the study, found 7 species on Sembulang Beach, namely: Archaster typicus, Craspidaster hesperus, Protoreaster nodosus, Holothuria atra, Holothuria scabra, Synapta maculata, and Synapta sp., with a Diversity Index value 1.92, Evennes Index 0.69, and Dominance Index 0.08. While on Melayu Beach, found 2 species, namely: A. typicus dan Cucumarid sp., with a Diversity Index value 0.08, Evennes Index 0.41, and Dominance Index 0.98. The Similarity Index Value of Asteroidea and Holothuroidea communities at Sembulang Beach and Melayu Beach is 0.22 (low).

Keywords: Community Structure, Asteroidea, Holothuroidea, Rempang Island.

\section{PENDAHULUAN}

Bintang laut (Asteroidea) dan Ketimun Laut (Holothuroidea) adalah dua dari 5 kelas yang berada dalam hewan filum Echinodermata (Lane dan Vandenspiegel, 2003). Asteroidea disebut juga Bintang laut karena memiliki bentuk tubuh seperti bintang pentamerous dan umumnya memiliki 5 buah lengan. Sedangkan Holothuroidea disebut juga Ketimun laut 
karena bentuk tubuhnya panjang dan silindris. Semua jenis hewan ini hidup di laut dan umumnya dijumpai pada daerah pantai terutama di daerah terumbu karang (Suwignyo et al., 2005; Oktavia, 2018).

Pantai Sembulang dan Pantai Melayu adalah dua pantai yang terletak di Pulau Rempang Kecamatan Galang Kota Batam Provinsi Kepulauan Riau. Pantai Sembulang merupakan pantai berpasir dan sedikit berlumpur dengan air laut yang jernih, serta terdapat hamparan padang lamun yang cukup luas. Biota laut yang umumnya tinggal di ekosistem padang lamun dan terumbu karang termasuk kelompok Asteroidea dan Holothuroidea (Budiman et al., 2014). Lokasi pantai ini berdekatan dengan pemukiman dan dermaga. Kegiatan transportasi laut ke lokasi pantai ini hampir ada di setiap harinya. Wisatawan yang datang berkunjung didominasi wisatawan lokal. Sedangkan Pantai Melayu merupakan tempat wisata yang lebih ramai dikunjungi wisatawan, karena jawak dan waktu tempuh ke lokasi yang mudah dijangkau serta ketersediaan fasilitas umum yang cukup memadai. Selain itu, pantai ini memiliki substrat pasir putih dan air yang jernih. Perbedaan substrat dan intensitas pengunjung di kedua pantai tersebut, menyebabkan adanya perbedaan keberagaman jenis Asteroidea dan Holothuroidea yang hidup di masing-masing pantai tersebut.

Keberadaan hewan ini di alam saat ini terus menyusut dikarenakan eksploitasi yang berlebihan. Kondisi ini disebabkan oleh nilai ekonomi kedua hewan ini yang relatif tinggi, khususnya Holothuroidea. Hewan ini merupakan komoditas ekspor dengan negara tujuan utama Hongkong (Suwignyo et al., 2005). Kisaran harga pasar domestik antara Rp. 2-6 juta/kilo, dengan jenis yang mendominasi adalah H. scabra (Romimohtarto dan Juwana, 2009). Sedangkan kelas Asteroidea, masih sangat sedikit dimanfaatkan dan hanya terbatas sebagai aksesoris atau ornamen kering dengan harga relatif murah (Purwati dan Arbi, 2012).

Asteroidea dan Holothuroidea yang ada di Pantai Sembulang dan Pantai Melayu Pulau Rempang ini belum diketahui jenisnya. Selain itu, penelitian sejenis diketahui masih sangat minim pada kedua kawasan pantai ini. Oleh karena itu, perlu dilakukan penelitian guna mendata jenis-jenis Asteroidea dan Holothuroidea. Penelitian ini bertujuan untuk mengetahui jenis-jenis serta stuktur komunitas Asteroidea dan Holothuroidea yang ada di Pantai Sembulang dan Pantai Melayu Pulau Rempang.

\section{METODE PENELITIAN}

Penelitian dilakukan pada bulan Juli-Agustus 2020. Pengambilan data dilaksanakan di Pulau Rempang, tepatnya pada pantai bagian Timur yaitu Pantai Sembulang dan pantai bagian Barat yaitu Pantai Melayu. Kedua pantai ini adalah memiliki ekosistem pantai berpasir, terumbu karang, dan padang lamun yang diyakini menjadi habitat Asteroidea dan Holothuroidea. Penetapan kedua pantai ini sebagai stasiun pengamatan diharapkan dapat mewakili kondisi struktur komunitas Asteroidea dan Holothuroidea di Pulau Rempang, karena telah mewakili pantai sisi Timur dan Barat pulau kecil tersebut. Alat yang digunakan dalam penelitian yaitu, Global Positioning System (GPS) untuk menetapkan titik koordinat plot pengamatan, kamera untuk dokumentasi, ember untuk penyimpanan sementara spesimen yang diambil, toples untuk penyimpanan dan pengawetan spesimen, kertas label untuk memberi identitas spesimen, alat tulis untuk mencatat, roll meter untuk menetapkan transek garis, $\mathrm{pH}$ meter untuk mengukur $\mathrm{pH}$ air, thermometer untuk mengukur suhu air, hand refractometer untuk mengukur salinitas air, dan buku panduan identifikasi untuk mengidensitikasi setiap 
jenis Asteroidea dan Holothuroidea yang ditemukan. Sedangkan bahan yang digunakan yaitu alkohol $70 \%$ untuk pengawetan spesimen.

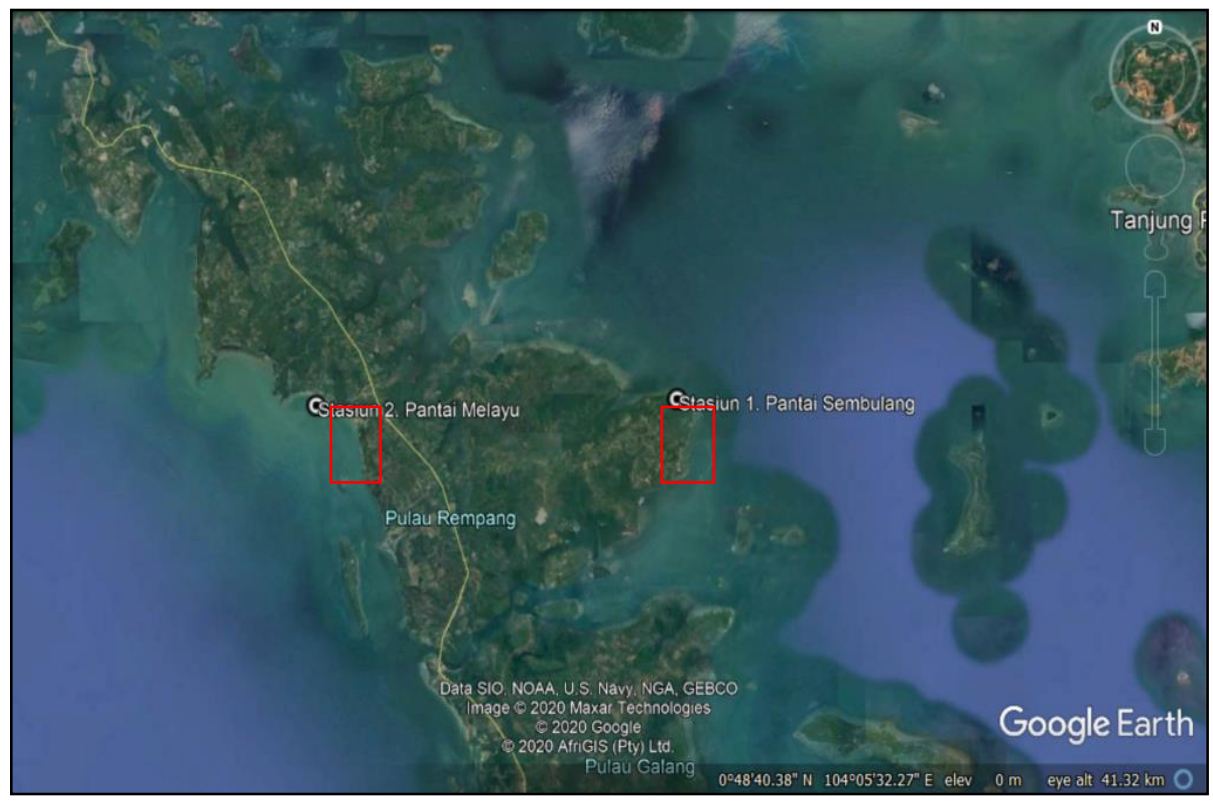

Gambar 1. Lokasi Stasiun Sampling Penelitian

Penelitian ini merupakan jenis penelitian eksplorasi dan pengambilan contoh dilakukan dengan metode line transects. Stasiun 1 terletak di Pantai Sembulang dan Stasiun 2 terletak di Pantai Melayu. Pada setiap stasiun ditetapkan 3 line transects, dengan panjang masing-masing transek 100 meter dan lebar 20 meter (10 meter ke kanan dan kiri masing-masing line transects), sedangkan jarak antar transek adalah 20 meter. Pengambilan sampel dilakukan pada saat air laut surut.

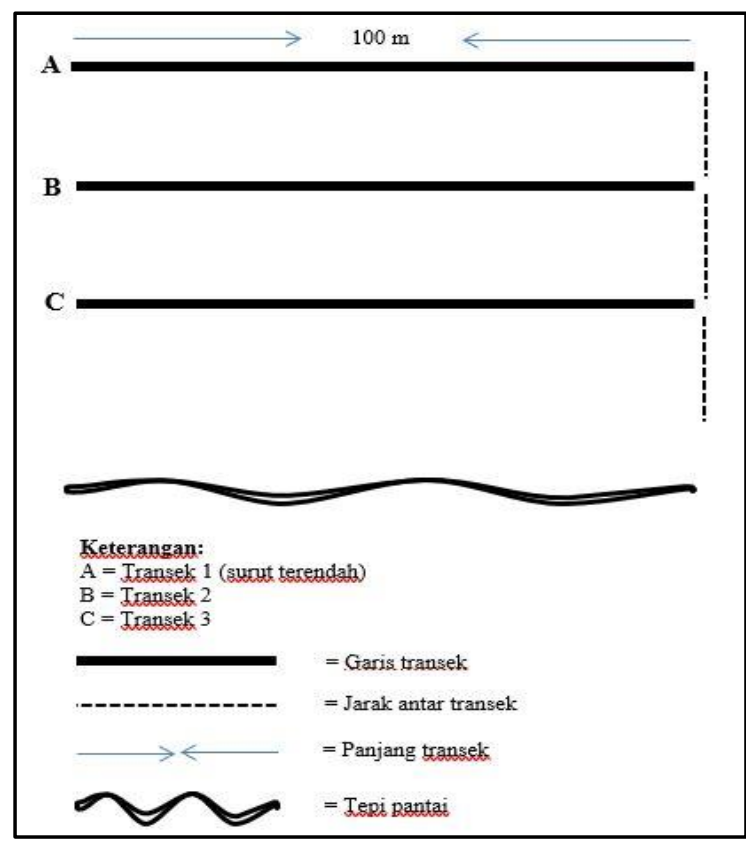

Gambar 2. Ilustrasi Penempatan Transek

Selain itu, pengambilan data parameter lingkungan juga dilakukan. Parameter lingkungan diukur secara insitu pada setiap lokasi pengamatan. Parameter yang diukur yaitu: 
suhu, derajat keasaman air $(\mathrm{pH})$, salinitas, jenis substrat pada lokasi pengamatan, serta tipe habitat hewan Asteroidea dan Holothuroidea. Pengambilan data parameter lingkungan ini diambil sebagai data pendukung untuk mengetahui komponen abiotik dari habitat Asteroidea dan Holothuroidea.

\section{Analisis Data}

\section{Indeks Keanekaragaman Jenis (H')}

Untuk mengetahui keanekaragaman jenis Asteroidea dan Holothuroidea, maka digunakan Indeks Keanekaragaman Shannon-Wienner, dengan rumus sebagai berikut (Odum, 1996):

$$
H^{\prime}=\sum\left(\frac{n_{i}}{N} \times \log _{2} \frac{n_{i}}{N}\right)
$$

Keterangan: $\mathrm{H}^{\prime}=$ Indeks Keanekaragaman Shannon-Wienner, $\mathrm{n}_{\mathrm{i}}=$ Jumlah individu spesies ke-i, $\mathrm{N}=$ Jumlah total individu. Kriteria nilai: $0 \leq \mathrm{H}<1=$ Tingkat keanekaragaman jenis rendah; $1 \leq \mathrm{H}<3=$ Tingkat keanekaragaman jenis sedang; $\mathrm{H} \geq 3$ = Tingkat keanekaragaman jenis tinggi.

\section{Indeks Keseragaman (E)}

Keseragaman atau kemerataan jenis dihitung menggunakan rumus Indeks Keseragaman Jenis Evennes sebagai berikut (Odum, 1996):

$$
E=\frac{H^{\prime}}{\log _{2} S}
$$

Keterangan: E = Indeks keseragaman Evennes, H' = Indeks keanekaragaman ShanonWienner, $\mathrm{S}=$ Jumlah spesies. Kriteria nilai: $0 \leq \mathrm{E}<0,3=$ Tingkat keseragaman jenis rendah; $0,3 \leq \mathrm{E}<0,6=$ Tingkat keseragaman jenis sedang, $0,6 \leq \mathrm{E}<1=$ Tingkat keseragaman jenis tinggi.

\section{Indeks Dominansi (D)}

Dominansi dihitung dengan menggunakan Indeks Dominansi dari Simpson sebagai berikut (Odum, 1996):

$$
D=\sum\left(\frac{n_{i}}{N}\right)^{2}
$$

Keterangan: $\mathrm{D}=$ Indeks Dominansi, $\mathrm{n}_{\mathrm{i}}=$ Kelimpahan jenis ke-i, $\mathrm{N}=$ Kelimpahan total seluruh jenis Asteroidea dan Holothuroidea. Kriteria nilai: $0 \leq \mathrm{D}<0,3=$ Tingkat dominansi jenis rendah; $0,3 \leq \mathrm{D}<0,6=$ Tingkat dominansi jenis sedang; $0,6 \leq \mathrm{D}<1=$ Tingkat dominansi jenis tinggi.

\section{Indeks Kesamaan (IS)}

Untuk mengetahui kesamaan jenis diantara kedua komunitas digunakan rumus Indeks Sorensen $\left(\mathbf{C}_{\mathrm{s}}\right)$ (Odum, 1996):

$$
C_{s}=\frac{2 j}{a+b}
$$

Keterangan: $\mathrm{j}=$ Jumlah spesies yang ditemukan pada kedua komunitas, $a=$ Jumlah spesies yang terdapat pada komunitas pertama, $\mathrm{b}=$ Jumlah spesies yang terdapat pada komunitas kedua. Kriteria nilai: 0,00 - 0,31 = Kesamaan atau similaritas rendah; 0,31 - 0,60= Kesamaan atau similaritas sedang; 0,61 - 1 = Kesamaan atau similaritas tinggi. 


\section{HASIL DAN PEMBAHASAN}

Pantai Sembulang terletak di titik koordinat sekitar 0 $01^{\prime} 6,27^{\prime \prime} \mathrm{N} 104^{\circ} 8^{\prime} 49,338^{\prime \prime} \mathrm{E}$, sedangkan Pantai Melayu terletak di titik koordinat sekitar 050'42,618” N 104¹5'44,754 E. Adapun tipe habitat di Pantai Sembulang yaitu pantai pasir berlumpur, padang lamun, dan terumbu karang. Sedangkan tipe habitat di Pantai Melayu yaitu pantai berpasir dan padang lamun. Jenis habitat dan parameter lingkungan yang diamati di masing-masing stasiun dapat dilihat pada tabel berikut:

Tabel 1. Hasil Pengamatan Faktor Lingkungan pada Lokasi Penelitian

\begin{tabular}{|c|c|c|c|c|}
\hline \multirow{2}{*}{ Lokasi } & \multicolumn{3}{|c|}{ Parameter Lingkungan } & \multirow{2}{*}{ Jenis Habitat } \\
\hline & Suhu $\left({ }^{\circ} \mathrm{C}\right)$ & pH & Salinitas (\%o) & \\
\hline $\begin{array}{l}\text { Stasiun } 1 \text { (Pantai } \\
\text { Sembulang) }\end{array}$ & $29^{\circ} \mathrm{C}$ & 8.3 & $20 \%$ & $\begin{array}{l}\text { Pantai pasir berlumpur, } \\
\text { padang lamun dan terumbu } \\
\text { karang }\end{array}$ \\
\hline $\begin{array}{l}\text { Stasiun2 (Pantai } \\
\text { Melayu) }\end{array}$ & $30^{\circ} \mathrm{C}$ & 8.1 & $25 \%$ & $\begin{array}{l}\text { Pantai pasir dan Padang } \\
\text { lamun }\end{array}$ \\
\hline
\end{tabular}

Adapun jenis habitat berdasarkan transek di masing-masing stasiun dapat dilihat pada tabel berikut.

Tabel 2. Penyebaran Asteroidea dan Holothuroidea Berdasarkan Jenis Habitatnya

\begin{tabular}{|c|c|c|c|c|c|c|c|c|c|c|c|c|c|c|c|}
\hline \multirow{3}{*}{ Spesies } & \multicolumn{9}{|c|}{ Pantai Sembulang } & \multicolumn{6}{|c|}{ Pantai Melayu } \\
\hline & \multicolumn{3}{|c|}{1} & \multicolumn{3}{|c|}{2} & \multicolumn{3}{|c|}{3} & \multicolumn{2}{|c|}{1} & \multicolumn{2}{|c|}{2} & \multicolumn{2}{|c|}{3} \\
\hline & $\mathbf{P b}$ & $\mathbf{L}$ & $\mathbf{K}$ & $\mathbf{P b}$ & $\mathbf{L}$ & $\mathbf{K}$ & $\mathbf{P b}$ & $\mathbf{L}$ & $\mathbf{K}$ & $\mathbf{P}$ & $\mathbf{L}$ & $\mathbf{P}$ & $\mathbf{L}$ & $\mathbf{P}$ & $\mathbf{L}$ \\
\hline \multicolumn{16}{|l|}{ Kelas Asteroidea } \\
\hline Archaster typicus & + & + & - & + & - & - & + & - & - & + & + & + & - & + & - \\
\hline Craspidaster hesperus & - & + & - & - & - & - & - & - & - & - & - & - & - & - & - \\
\hline Protoreaster nodosus & - & + & - & - & - & - & - & - & - & - & - & - & - & - & - \\
\hline \multicolumn{16}{|l|}{ Kelas Holothuroidea } \\
\hline Cucumarid sp. & - & - & - & - & - & - & - & - & - & + & - & - & - & - & - \\
\hline Holothuria atra & - & + & - & - & - & - & - & - & - & - & - & - & - & - & - \\
\hline Holothuria scabra & - & + & - & - & - & - & - & - & - & - & - & - & - & - & - \\
\hline Synapta maculata & - & + & - & - & - & - & - & - & - & - & - & - & - & - & - \\
\hline Synapta sp. & - & - & - & - & + & - & - & - & - & - & - & - & - & - & - \\
\hline
\end{tabular}

Keterangan: (+): Ada; (- ) : Tidak Ada; $\mathrm{P}=$ Pasir; $\mathrm{Pb}=$ Pasir berlumpur; $\mathrm{L}=$ Padang Lamun; $\mathrm{K}=$ Terumbu Karang

Pada Tabel 2 dapat dilihat bahwa di Pantai Sembulang pada transek 1, hewan Asteroidea dan Holothuroidea yang ditemukan di habitat padang lamun sebanyak 6 jenis, 3 jenis dari kelas Asteroidea yaitu A. typicus, C. hesperus, dan P. nodosus; dan 3 jenis dari kelas Holothuroidea yaitu $H$. scabra, H. atra, dan S. maculata. Sedangkan pada jenis habitat pasir berlumpur terdapat 1 jenis yaitu A. typicus. Pada transek 2, kelompok Asteroidea yang menempati substrat pasir berlumpur hanya 1 jenis yaitu A. typicus; dan juga 1 jenis kelompok Holothuroidea yang menempati habitat padang lamun yaitu Synapta sp. Pada transek 3 hanya 
1 jenis dari kelompok hewan Asteroidea yang menempati habitat pasir berlumpur, yaitu $A$. typicus.

Di Pantai Melayu, pada transek 1, hewan Asteroidea dan Holothuroidea yang ditemukan di habitat pasir terdapat 2 jenis, 1 jenis kelompok hewan Asteroidea yaitu A. typicus; dan 1 jenis hewan Holothuroidea yaitu Cucumarid sp.; selanjutnya pada habitat padang lamun ditemukan 1 jenis yaitu A. typicus. Pada transek 2 dan 3 hanya 1 jenis kelompok hewan Asteroidea yang menempati habitat pasir yaitu A. typicus.

Spesies yang paling banyak ditemukan di kedua pantai ini adalah A. typicus dan menempati berbagai habitat seperti pantai berpasir, pasir berlumpur, dan padang lamun. Pada penelitian Irawan (2014) di Perairan Litoral Pesisir Timur Pulau Bintan juga didapatkan informasi bahwa A. typicus selalu ditemukan pada semua lokasi, dimana ada kesamaan habitat yaitu di daerah litoral pesisir berpasir, terutama di habitat pasir berlumpur di sekitar padang lamun dan batu karang. Pada penelitian Aziz (1996), jenis bintang laut A. typicus dan Astropecten polycanthus ditemukan pada rataan pasir; Echinaster luzonicus dan Protoreaster nodosus adalah jenis bintang laut yang lebih sering dijumpai di padang lamun. Pulau Rempang memiliki beragam habitat, yaitu pantai berpasir, pantai pasir berlumpur, padang lamun, dan terumbu karang. Keberadaannya merupakan tempat hidup berbagai biota laut termasuk hewan Echinodermata khususnya kelompok hewan Asteroidea dan Holothuroidea.

Tabel 3. Jenis-jenis Asteroidea dan Holothuroidea yang Ditemukan di Lokasi Penelitian

\begin{tabular}{|c|c|c|c|}
\hline \multirow[b]{2}{*}{ Spesies } & \multicolumn{2}{|c|}{ Jumlah Individu } & \multirow{2}{*}{$\Sigma$ Individu } \\
\hline & Pantai Sembulang & Pantai Melayu & \\
\hline \multicolumn{4}{|l|}{ Kelas Asteroidea } \\
\hline Archaster typicus & 10 & 100 & 110 \\
\hline Craspidaster Hesperus & 1 & 0 & 1 \\
\hline Protoreaster nodosus & 1 & 0 & 1 \\
\hline \multicolumn{4}{|l|}{ Kelas Holothuroidea } \\
\hline Cucumarid sp. & 0 & 1 & 1 \\
\hline Holothuria atra & 1 & 0 & 1 \\
\hline Holothuria scabra & 1 & 0 & 1 \\
\hline Synapta maculate & 1 & 0 & 1 \\
\hline Synapta sp. & 1 & 0 & 1 \\
\hline Total Individu & 16 & 101 & 117 \\
\hline$\Sigma$ Spesies & 7 & 2 & \\
\hline
\end{tabular}

Dari tabel di atas dapat dilihat bahwa pada Stasiun 1 (Pantai Sembulang) spesies yang banyak dijumpai adalah $A$. typicus dengan jumlah 10 individu, dan spesies yang paling sedikit dijumpai adalah $C$. hesperus, P. nodosus, H. scabra, H. atra, S. maculate, dan Synapta sp. dengan jumlah masing-masing 1 individu. Sedangkan pada Stasiun 2 (Pantai Melayu) spesies yang banyak dijumpai adalah A. typicus dengan jumlah 100 individu, dan spesies yang paling sedikit dijumpai adalah Cucumarid sp. dengan jumlah 1 individu. Pada penelitian Irawan (2014) di Perairan Litoral Pesisir Timur Pulau Bintan, ditemukan 4 spesies hewan Asteroidea dan 5 spesies hewan Holothuroidea, empat diantaranya sama dengan jenis yang ditemukan pada penelitian ini, yaitu A. typicus, P. nodosus, H. scabra, dan H. atra. Selanjutnya pada penelitian Lalombombuida et al., (2019) di Pantai Paranti Desa Tabang, Kecamatan Rainis 
Kabupaten Kepulauan Talaud Provinsi Sulawesi ditemukan lebih banyak spesies Asteroidea dan Holothuroidea, yakni 5 spesies hewan Asteroidea dan 8 spesies Holothuroidea, terdapat 5 spesies yang sama pada penelitian ini, yaitu A. typicus, $P$. nodosus, $H$. scabra, $H$. atra, dan $S$. maculata. Pada penelitian Katili (2011) di Zona Intertidal Gorontalo, ditemukan 4 spesies hewan Asteiroidea dan 3 spesies hewan Holohuroidea, dua diantaranya sama dengan spesies yang ditemukan pada penelitian ini, yaitu A. typicus dan H. scabra.

\section{Analisis Struktur Komunitas Asteroidea dan Holothuroidea Indeks Keanekaragaman jenis (H')}

Dari hasil penelitian yang telah dilakukan di Pantai Sembulang dan Pantai Melayu, diperoleh nilai indeks keanekaragaman pada masing-masing stasiun dan juga pada masingmasing transek. Transek 1 berada di garis surut terendah, sedangkan Transek 2 dan 3 masingmasing berjarak 20 meter menuju tepi pantai.

Berdasarkan hasil penelitian yang telah dilakukan di Pantai Sembulang, pada Transek 1 diperoleh nilai indeks keanekaragaman sebesar 2,05 yang tergolong dalam kategori sedang, Transek 2 nilai indeks keanekaragaman adalah 0,81 tergolong dalam kategori rendah, dan Transek 3 nilai indeks keanekaragaman adalah 0 atau tidak menunjukkan tingkat keanekaragaman. Hasil indeks keanekaragaman jenis Asteroidea dan Holothuroidea pada masing-masing transek di Pantai Sembulang dapat dilihat pada Gambar 3.



Gambar 3. Indeks Keanekaragaman Asteroidea dan Holothuroidea pada Masing-masing Transek pada Stasiun 1 (Pantai Sembulang).

Sedangkan di Pantai Melayu, pada Transek 1 diperoleh nilai indeks keanekaragaman adalah 0,18, Transek 2 nilai Indeks Keanekaragaman Jenis adalah 0, dan Transek 3 nilai Indeks Keanekaragaman Jenis adalah 0. Hasil Indeks keanekaragaman jenis Asteroidea dan Holothuroidea pada masing-masing transek di Pantai Sembulang dapat dilihat pada Gambar 4. Kemudian hasil perhitungan dari indeks keanekaragaman pada tiap stasiun diperoleh nilai indeks keanekaragaman di Pantai Sembulang lebih tinggi daripada Pantai Melayu. Nilai indeks keanekaragaman di Pantai Sembulang termasuk dalam kategori sedang 
(dengan nilai indeks keanekaragaman $\mathrm{H}^{\prime}=1,92$ ), sedangkan di Pantai Melayu termasuk dalam kategori rendah (dengan nilai indeks keanekaragaman $\mathrm{H}^{\prime}=0,08$ ).

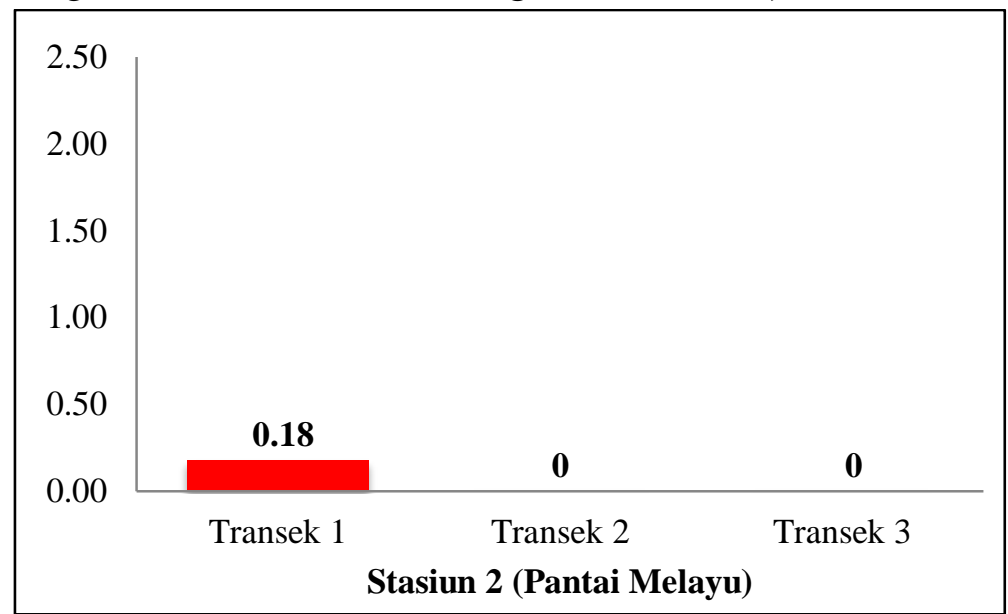

Gambar 4. Indeks Keanekaragaman Jenis Asteroidea dan Holothuroidea pada Masing-masing Transek di Pantai Melayu.

Pada penelitian Yudi et al., (2017) di Perairan Tanjung Kelit Senayang Lingga Kepulauan Riau, diperoleh nilai indeks keanekaragaman sebesar 2,09 yang termasuk dalam kategori sedang, namun indeks keanekaragaman ini dihitung untuk keseluruhan kelas Echinodermata yang ditemukan di lokasi tersebut. Hasil analisis Indeks Keanekaragaman Jenis Asteroidea dan Holothuroidea di Pantai Sembulang dan Pantai Melayu dapat disajikan pada Gambar 5.



Gambar 5. Indeks Keanekaragaman Jenis Asteroidea dan Holothuroidea pada Stasiun 1

(Pantai Sembulang), dan Stasiun 2 (Pantai Melayu).

Pada gambar di atas menunjukkan nilai indeks keanekaragaman di Stasiun 1 (Pantai Sembulang) dan Stasiun 2 (Pantai Melayu) memiliki selisih angka yang cukup berbeda. Tingkat keanekaragaman dikatakan tinggi apabila jumlah per jenis menyebar secara merata atau jumlah individu tiap jenis relatif sama (Erlangga et al., 2018). Menurut Supono dan Arbi (2010) dalam Budiman et al., (2014), tinggi rendahnya nilai indeks keanekaragaman dapat disebabkan oleh berbagai faktor, yaitu jumlah jenis atau individu yang didapat, adanya beberapa jenis yang ditemukan dalam jumlah yang melimpah, homogenitas substrat, dan kondisi dari tiga ekosistem penting di daerah pesisir (yaitu padang lamun, terumbu karang dan hutan mangrove) sebagai habitat biota perairan. Pada penelitian ini, kedua stasiun penelitian 
memiliki jenis habitat yang berbeda. Pantai Sembulang memiliki jenis habitat yang beragam, yaitu: pasir berlumpur, padang lamun, dan terumbu karang. Dengan begitu, lebih banyak spesies yang ditemukan dan dapat menunjang kelangsungan hidup Asteroidea dan Holothuroidea. Sedangkan Pantai Melayu memiliki jenis habitat pasir dan sedikit lamun. Selain itu di Pantai Melayu terdapat spesies yang memiliki jumlah individu yang dominan, yaitu A. typicus dengan jumlah 100 individu. Menurut pendapat Nurafni et al. (2019), tingginya nilai keanekaragaman jenis dikarenakan jumlah spesies dan jumlah masing-masing individu yang ditemukan banyak dan hampir merata. Sebaliknya rendahnya nilai keanekaragaman jenis yang diperoleh dikarenakan jumlah masing-masing individu yang diperoleh tidak merata.

\section{Indeks Keseragaman Jenis (E) dan Indeks Dominansi Jenis (D)}

Hasil perhitungan nilai indeks keseragaman jenis (E) yang diperoleh di Pantai Sembulang (Stasiun 1) pada masing-masing transek berturut-turut adalah 0,79, 0,81, dan 0 . Pada Transek 1 dan 2 diperoleh nilai indeks keseragaman jenis yang hampir sama, dengan kategori tinggi;sedangkan pada Transek 3 nilai indeks keseragaman rendah. Hasil perhitungan indeks keseragaman jenis dan indeks dominansi jenis pada masing-masing transek di tiap stasiun disajikan pada Gambar 6.

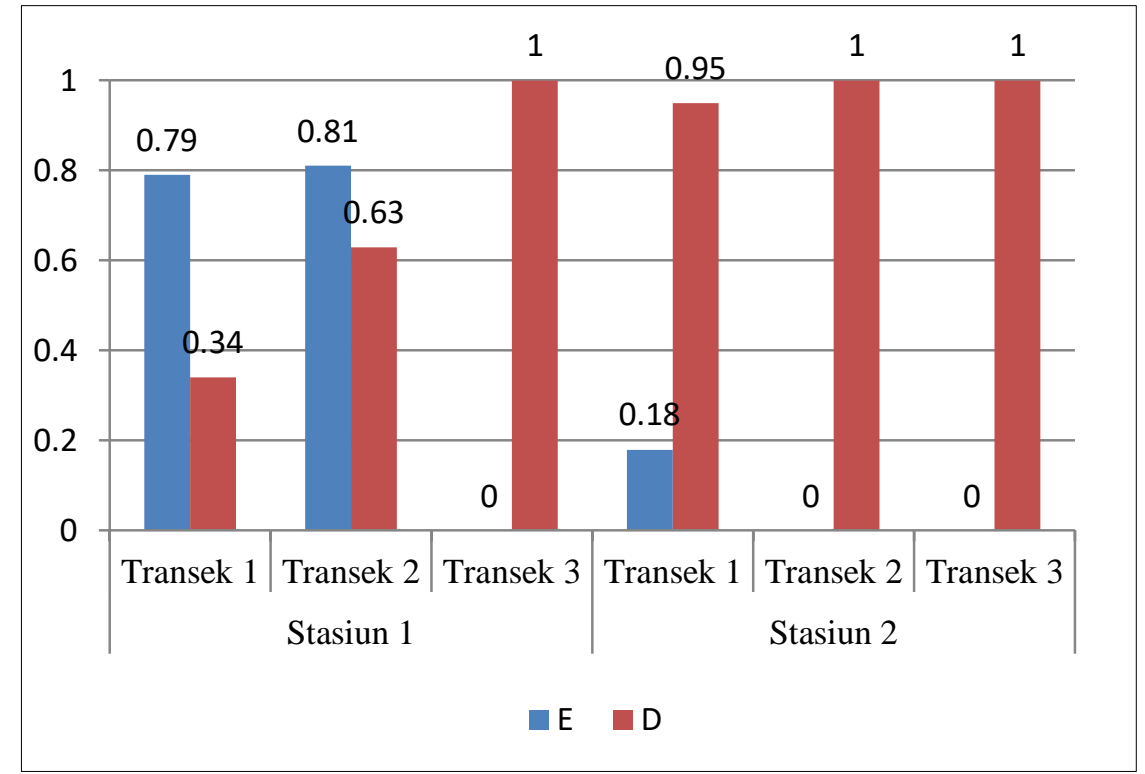

Gambar 6. Indeks Keseragaman (E) dan Indeks Dominansi (D) pada Masing-Masing Transek di Pantai Sembulang dan Pantai Melayu.

Hasil perhitungan indeks keseragaman jenis pada Stasiun 2 Pantai Melayu di masingmasing transek tergolong kategori rendah. Pada Transek 1 diperoleh nilai indeks keseragaman jenis 0,18 dan pada Transek 2 dan 3 nilai indeks keseragaman jenis adalah 0. Hasil perhitungan nilai indeks dominansi jenis di Pantai Sembulang berbeda-beda. Pada Transek 1 sebesar 0,34 (termasuk dalam kategori sedang), Transek 2 sebesar 0,63 (termasuk dalam kategori tinggi), dan Transek 3 sebesar 1 (termasuk dalam kategori tinggi). Hasil perhitungan nilai indeks dominansi jenis di Pantai Melayu pada masing-masing transek hampir sama, yaitu tergolong dalam kategori tinggi. Pada Transek 1 diperoleh hasil indeks dominansi jenis 
sebesar 0,95, dan diikuti Transek 2 dan 3 masing-masing diperoleh nilai indeks dominansi Jenis sebesar 1.

Dari hasil perhitungan nilai indeks keseragaman jenis di tiap stasiun, diperoleh nilai Indeks Keseragaman Jenis pada Stasiun 1 Pantai Sembulang lebih tinggi daripada Stasiun 2 di Pantai Melayu. Di Stasiun 1 diperoleh hasil sebesar 0,69 (tergolong dalam kategori tinggi), dan Stasiun 2 diperoleh hasil sebesar 0,41 (tergolong dalam kategori sedang).

Menurut Suwartimah et al., (2017), semakin kecil nilai indeks keseragaman jenis dalam komunitas (mendekati 0), artinya penyebaran jumlah individu setiap spesies tidak sama, yaitu terdapat kecenderungan bahwa komunitas tersebut didominasi oleh spesies tertentu. Sebaliknya, bila semakin besar nilai indeks keseragaman jenis dalam komunitas (mendekati 1), maka artinya kelimpahan setiap spesies dapat dikatakan sama atau tidak jauh berbeda, dan di dalam komunitas tersebut tidak ada dominasi. Hal ini menunjukkan bahwa keseragaman spesies di Pantai Sembulang maupun di Pantai Melayu tidak jauh berbeda. Jumlah individu antar spesies dalam masing-masing komunitas hampir sama. Semakin merata penyebaran individu antar jenis, maka keseimbangan ekosistem akan semakin meningkat (Erlangga et al., 2018).

Sedangkan hasil dari perhitungan nilai indeks dominansi jenis pada masing-masing stasiun, diperoleh nilai Indeks Dominansi Jenis di Pantai Melayu lebih tinggi daripada di Pantai Sembulang. Kisaran nilai indeks dominansi jenis di antara dua stasiun ini sangat berbeda. nilai indeks dominansi jenis di Pantai Sembulang adalah 0,08 (termasuk dalam kategori rendah), sedangkan di Pantai Melayu adalah 0,98 (termasuk dalam kategori tinggi). Hal ini dikarenakan di Pantai Sembulang komposisi jenis atau penyebaran individu seimbang, sehingga tidak ada jenis yang terlalu mendominasi. Sedangkan di Pantai Melayu ditemukan spesies yang dominan, yaitu A. typicus. nilai indeks keseragaman jenis dan indeks dominansi jenis masing-masing stasiun dapat dilihat pada Gambar 7.

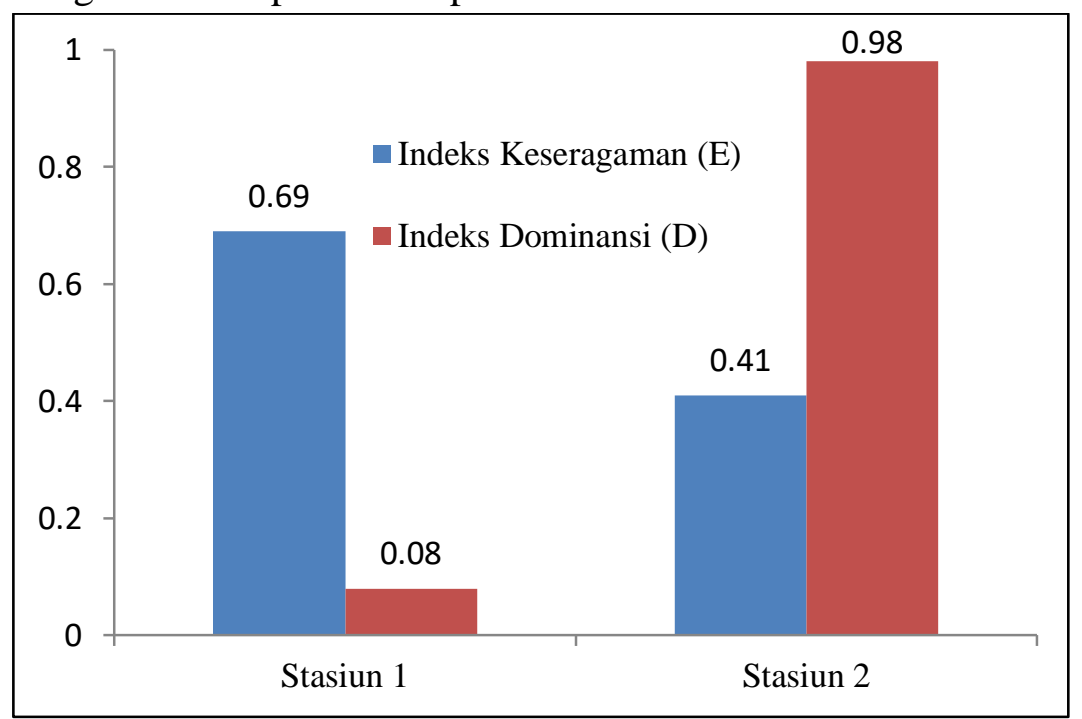

Gambar 7. Indeks Keseragaman (E) dan Indeks Dominansi (D) pada Stasiun 1 (Pantai Sembulang) dan Stasiun 2 (Pantai Melayu)

\section{Indeks Kesamaan (IS)}

Hasil perhitungan nilai indeks kesamaan jenis Asteroidea dan Holothuroidea di Pantai Sembulang dan Pantai Melayu nilai yang rendah, yaitu sebesar 0,22; artinya dari kedua komunitas tersebut memiliki kesamaan jenis yang sedikit atau tidak mirip. Dari 7 spesies yang 
ditemukan di Pantai Sembulang, hanya 1 spesies yang juga ditemukan di Pantai Melayu, yaitu A. typicus. Hal ini dikarenakan kedua pantai ini memiliki jenis habitat yang berbeda. Pantai Sembulang memiliki beragam habitat yang cocok untuk tempat hidup Asteroidea dan Holothuroidea, yaitu pasir berlumpur, padan lamun, dan terumbu karang; sedangkan Pantai Melayu hanya memiliki habitat pantai pasir dan sedikit lamun.

\section{KESIMPULAN}

Ditemukan sebanyak 7 spesies pada Stasiun 1 Pantai Sembulang yang terdiri dari 3 spesies kelas Asterioidea dan 4 spesies kelas Holothuroidea, dan sebanyak 2 spesies ditemukan pada Stasiun 2 Pantai Melayu untuk masing-masing kelas Asterioidea dan Holothuroidea. Indeks keaneakaragaman jenis Asterioidea dan Holotuhuroidea di Pantai Sembulang kategori sedang, sedangkan di Pantai Melayu kategori rendah. Indeks keseragaman jenis di Pantai Sembulang kategori tinggi, sedangkan di Pantai Melayu kategori sedang. Indeks dominansi jenis di Pantai Sembulang kategori rendah, sedangkan di Pantai Melayu kategori tinggi. Indeks kesamaan jenis di Pantai Sembulang dan Pantai Melayu menunjukkan kesamaan jenis yang rendah.

\section{REFERENSI}

Aziz, A. 1996. Habitat dan Zonasi Fauna Ekhinodermata di Ekosistem Terumbu Karang. Oseana, XXI(2): 33-43.

Budiman, C. C., Maabuat, P. V., Langoy, M. L., dan Katili, D. Y. 2014. Keanekaragaman Echinodermata di Pantai Basaan Satu Kecamatan Ratatotok Sulawesi Utara. Jurnal Mipa Unsrat Online, 3(2): 97-101.

Erlangga, Y., Rahimi, S. A. E1, dan Devira, C. N. 2018. Struktur Komunitas Echinodermata di Perairan Pantai Gapang, Desa Iboih, Kecamatan Sukakarya, Sabang. Jurnal Ilmiah Mahasiswa Kelautan Dan Perikan Unsyiah, 3(1): 92-101.

Irawan, H. 2014. Studi Biologi dan Ekologi Hewan Filum Echinodermata di Perairan Litoral Pesisir Timur Pulau Bintan. Dinamika Maritim, 4(2): 9-23.

Katili, A. S. 2011. Struktur Komunitas Echinodermata Pada Zona Intertidal di Gorontalo. Jurnal Penelitian Dan Pendidikan, 8(1): 51-61.

Lalombombuida, S., Langoy, M., dan Katili, D. Y. 2019. Keanekaragaman Echinodermata di Pantai Paranti Desa Tabang, Kecamatan Rainis Kabupaten Kepulauan Talaud Provinsi Sulawesi. Jurnal Perikanan Dan Kelautan Tropis, 10(2): 39-50.

Lane, D. J. W. and Vandenspiegel, D. 2003. A Guide Sea Stars and Other Echinoderms of Singapore. Singapore Science Centre. Singapore.

Nurafni, Muhammad, S. H., dan Sibua, I. 2019. Keanekaragaman Echinodermata di Perairan Pulau Ngele Ngele Kecil, Kabupaten Pulau Morotai. Jurnal Ilmu Kelautan Kepulauan, 2(2): 74-83.

Odum, E. P. 1996. Dasar-Dasar Ekologi. (Edisi 3), Penerjemah: T. Samingan. Gajah Mada University Press. Yogyakarta.

Oktavia, R. 2018. Inventarisasi Hewan Invertebrata di Perairan Pasir Putih Lhok Mee 
Kabupaten Aceh Besar. Bionatural, 5(1): 61-72.

Purwati, P. dan Arbi, U. Y. 2012. Karakteristik Morfologi Bintang Laut Untuk Identifikasi. Oseana, 37(1): 7-15.

Romimohtarto, K dan S. Juwana. 2009. Biologi Laut: Ilmu Pengetahuan Tentang Biologi Laut. (Edisi ke 4). Djembatan. Jakarta.

Suwignyo, S., Widigdo, B., Wardiatno, Y., dan Krisanti, M. 2005. Avertebrata Air Jilid 2. Penebar Swadaya. Depok.

Suwartimah, K., Wati, D. S., Endrawati, H., dan Hartati, R. 2017. Komposisi Echinodermata di Rataan Litoral Terumbu Karang Pantai Krakal, Gunung Kidul, Yogyakarta. Buletin Oseanografi Marina, 6(1): 53-60.

Yudi, Y., Karlina, I., dan Putra, R. D. 2017. Keanekaragaman Jenis Echinodermata di Perairan Tanjung Kelit Senayang Lingga Kepulauan Riau. [Skripsi]. Fakultas Ilmu Kelautan dan Perikanan Universitas Maritim Raja Ali Haji. Tanjungpinang.

\section{Autors:}

Hazlinda Frisca, Program Studi Pendidikan Biologi Universitas Riau Kepulauan, Jalan Pahlawan No.99, Bukit Tempayan, Batu Aji, Kota Batam, Provinsi Kepulauan Riau, (29425), Indonesia, email: hazlindafrisca21@gmail.com

Lani Puspita, Program Studi Pendidikan Biologi Universitas Riau Kepulauan, Jalan Pahlawan No.99, Bukit Tempayan, Batu Aji, Kota Batam, Provinsi Kepulauan Riau, (29425), Indonesia, email: puspita.lani@gmail.com Fauziah Syamsi, Program Studi Pendidikan Biologi Universitas Riau Kepulauan, Jalan Pahlawan No.99, Bukit Tempayan, Batu Aji, Kota Batam, Provinsi Kepulauan Riau, (29425), Indonesia, email: fauziahsyamsi@gmail.com

This is an open-access article distributed under the terms of the Creative Commons Attribution License, which permits unrestricted use, distribution and reproduction in any medium, provided the original author and source are credited. (http://creativecommons.org/licenses/by/4.0/).

\section{How to cite this article:}

Frisca, H., Puspita, L., and Syamsi, F. 2020. Structure community of Asteroidea dan Holothuroidea at Melayu and Sembulang Beach Rempang Island, Batam City. Simbiosa, 9(2): 138-149. Doi. http://dx.doi.org/10.33373/sim-bio.v9i2.2698 